\title{
BIOACTIVE SUBSTANCES IN TREES AND SHRUBS OF CENTRAL EUROPE
}

\author{
Lidia Szwajkowska-Michalek ${ }^{1}$, Anna Przybylska-Balcerek ${ }^{1}$, Tomasz Rogoziński ${ }^{2}$, Kinga \\ Stuper-Szablewska ${ }^{1}$ \\ ${ }^{1}$ Department of Chemistry Poznań University of Life Sciences ul. Wojska Polskiego 75 60-625 Poznań, Poland; \\ lidia.szwajkowska@up.poznan.pl ; ania_przybylska18@wp.pl, kinga.stuper@up.poznan.pl \\ ${ }^{2}$ Department of Furniture Design, Poznań University of Life Sciences ul. Wojska Polskiego 38/42 \\ 60-627 Poznań, Poland; trogoz@up.poznan.pl \\ correspondence: lidia.szwajkowska@up.poznan.pl ; Tel: +48-61-848-78-43
}

\begin{abstract}
Plants produce specific structures constituting a barrier hindering penetration of pathogens, while they also produce substances inhibiting pathogen growth. These compounds are secondary metabolites, such as phenolics, terpenoids, sesquiterpenoids, resins, tannins and alkaloids. Bioactive compounds are secendary metabolities from trees and shrubs are used in medicine, herbal medicine and cosmetology. To date fruits and flowers of exotic trees and shrubs have been primarily used as sources of bioactive compounds. In turn, search for new sources of bioactive compounds is currently focused on native plant species due to its availability. Application of such raw material needs to be based on knowledge of their chemical composition, particularly health-promoting or therapeutic compounds. Research conducted to date on European trees and shrubs has been scarce. This paper presents results of literature studies conducted to systematise knowledge on bioactive compounds found in trees and shrubs native to central Europe.

The aim of this review providing available information on the subject is to indicate gaps in the present knowledge.
\end{abstract}

Keywords: bioactive compounds from European trees and shrubs, gallic and cinnamic acids, quercetin, pinosylvin, $\beta$-sitosterol, alfa- and $\beta$-pinene

1. Biosynthesis of active substances

Tree stands are exposed to the action of stress factors, both abiotic and biotic. The former include weather anomalies, UV radiation, intensive lighting, water deficit, substrate salinity, high temperature amplitudes and the presence of heavy metals. In turn, biotic factors include pest insects, pathogenic fungi, bacteria and viruses. Trees counter stressors by initiating defence mechanisms to minimise or eliminate disturbances in growth and development. They are related with the consumption of energy and assimilates, limited production of biomass, its disadvantageous allocation as well as reduced reproduction. The action of biotic stressors is mainly connected with trees and woody plants entering into symbiosis with antagonists of pathogens, insects, etc.

Plants produce specific structures constituting a barrier hindering penetration of pathogens, e.g. resin canals, the presence of waxes and resins on their surface, while they also produce substances inhibiting pathogen growth and reducing attractiveness of needles, etc. These compounds are secondary metabolites, such as phenolics, terpenoids, sesquiterpenoids, resins, 
tannins and alkaloids. A considerable number of secondary metabolites protect against the adverse effect of herbivorous insects [1,2], pathogenic fungi [3-6] and bacteria [7,8]. These compounds differ in their chemical structure and are found both on the surface of plants and inside their tissues. Most of them are located in vacuoles and cell walls of peripheral tissues. They are also contained in resins secreted from bark and fruits. Secondary metabolites are most frequently synthesised via three metabolic pathways: terpenoid (mevalonate), phenolic (shikimate) and nitrogen metabolism (amino acids). For woody plants the derivatives of the shikimate pathways are of greatest importance, e.g. phenolic compounds (phenols, alcohols and phenolic acids, phenylpropanoids, flavonoids, coumarins, tannins), hydroxamic acids and indole alkaloids [9-11].

\subsection{The mevalonate pathway}

The mevalonate pathway is initiated in the cytosol of plant cells, producing sterols, sesquiterpenes and triterpenes. It leads to the formation of active isoprene, being the primary structural unit of terpenoids [12]. Products of this pathway belong to the class of terpenoids and are formed as a result of condensation of 3 acetyl-CoA molecules. This process includes also the synthesis of isopentenyl pyrophosphate and 3,3-dimethylallyl pyrophosphate, which are recondensed to form the above-mentioned terpenoids [13, 14]. The other pathway for the synthesis of isopentenyl pyrophosphate takes place in plastids, where carotenoids are produced (Figure 1) [15]. 


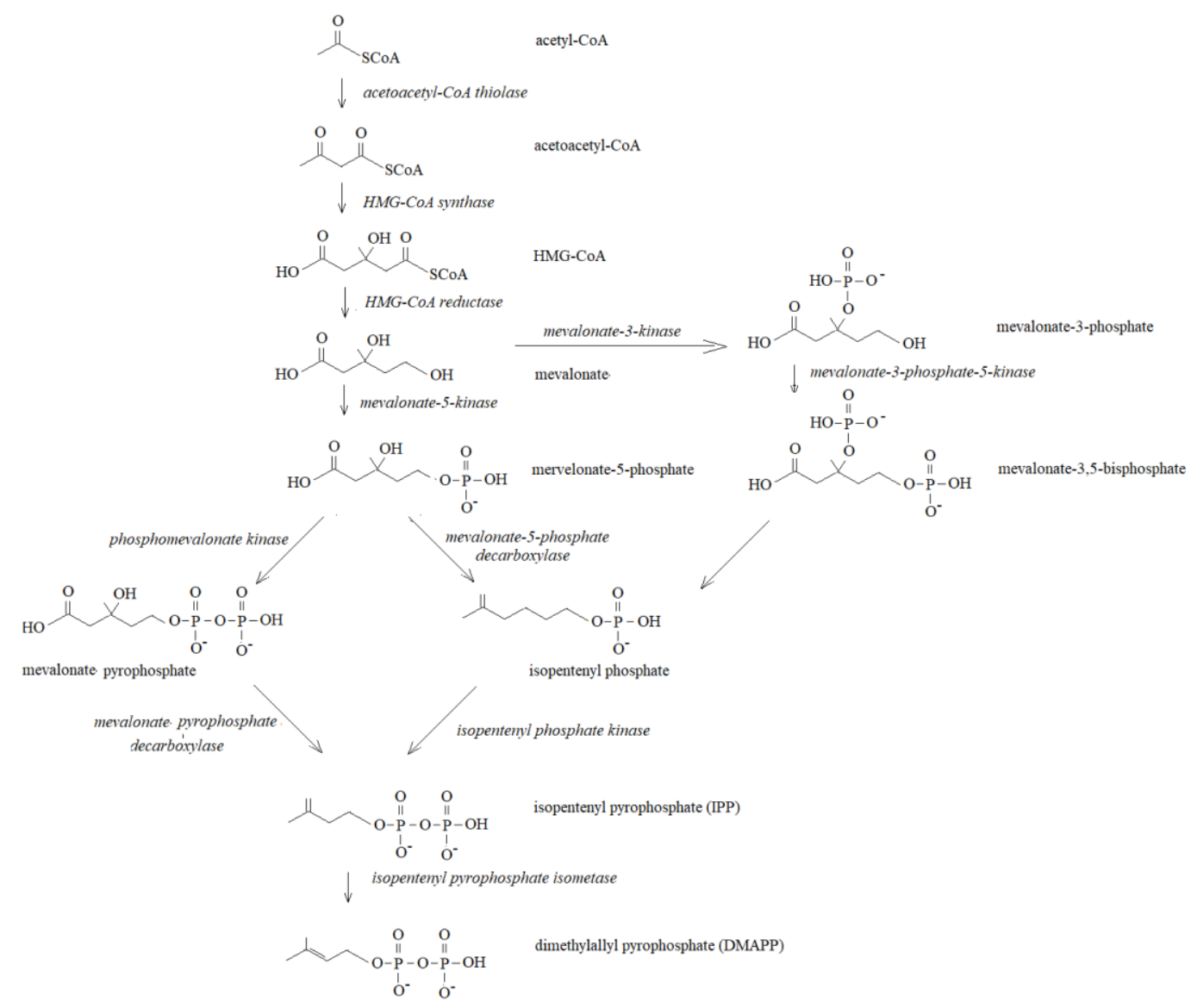

Figure 1. The mevalonate pathway

\subsection{The shikimate pathway}

This pathway plays an important role in the synthesis of many aromatic compounds in plants. In this pathway aromatic amino acids are formed, i.e. phenylalanine, tyrosine and tryptophan, used by higher plants as structural components of proteins and as precursors of secondary metabolites. In this process aromatic phenolic acids are produced, contained in complex structures of secondary metabolites, e.g. lignins [16, 17]. (Figure 2) They are synthesised in the reaction of phosphoenolpyruvate with erythrose-4-phosphate. 


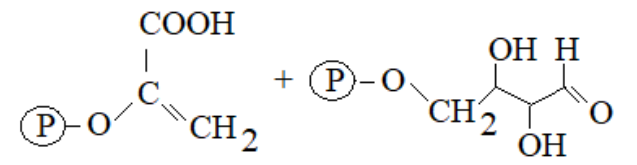

Phosphoetanol pyruvate Erythrose 4-phosphate

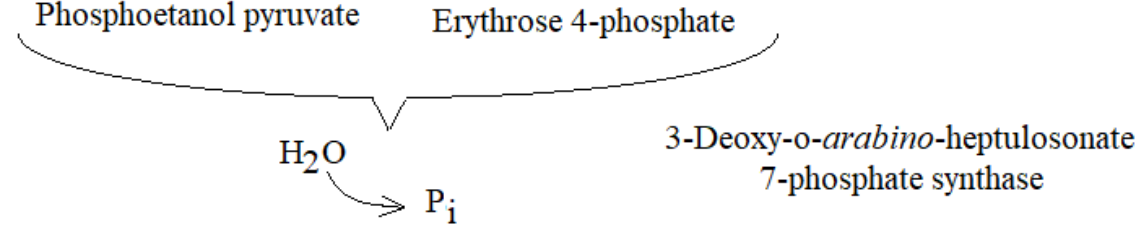<smiles>O=C(O)C1(O)CC(O)C(O)C(CO[Co])O1</smiles>

3-Deoxy-o-arabino-heptulosonate 7-phosphate<smiles>CC1CC1P</smiles>

3-Dehydroquinate synthase<smiles>O=C1CC(O)(C(=O)O)CC(O)C1O</smiles>

3-Dehydroquinate

3-Dehydroquinate dehydratase<smiles>O=C(O)C1=CC(=O)C(O)C(O)C1</smiles>

3-Dehydroshikimate

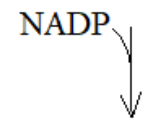

Shikimate dehydrogenase<smiles>O=C(O)C1=CC(O)C(O)C(O)C1</smiles>

Shikimate

Figure 2. The shikimate pathway

1.3 The nitrogen metabolism pathway 
Biosynthesis of amino acids begins with the assimilation of nitrogen ions occurring in several stages within the cytoplasm and plastids. Nitrates $(\mathrm{V})$ absorbed inside the cell are transformed to nitrites(III) by nitrate reductase present in the cytoplasm and thus formed $\mathrm{NO}_{2}{ }^{-}$ions, toxic for the cell, are transported to plastids, in which thanks to the action of nitrite reductase $\mathrm{NO}_{2}{ }^{-}$ ions are reduced to ammonium ions. The last stage in this process consists in the incorporation of $\mathrm{NH}_{4}{ }^{+}$into the structures of carbon skeletons and the formation of amino acids in the glutamine synthetase-glutamate synthase (GS-GOGAT) pathway $[18,19]$. Thus formed ammonium ions are transformed to glutamines by glutamine synthetase (GS1) and next to asparagine and glutamic acid by asparagine synthetase [19, 20, 21]. A significant role in the biosynthesis of amino acids is played by glutamate and glutamine. The former is synthesised from $\mathrm{NH}_{4}{ }^{+}$and $\alpha$-ketoglutarate with the participation of glutamate dehydrogenase. The ammonium ion $\left(\mathrm{NH}_{4}{ }^{+}\right)$was introduced to glutamine in the action of glutamine synthetase on glutamate. Amidation is dependent on the hydrolysis of ATP. The amino acid biosynthesis pathways vary in this respect (Figure 3) [22]. Their common characteristic is the fact that carbon skeletons originate from the intermediate compounds of glycolysis, the pentose phosphate pathway or the citric acid cycle.

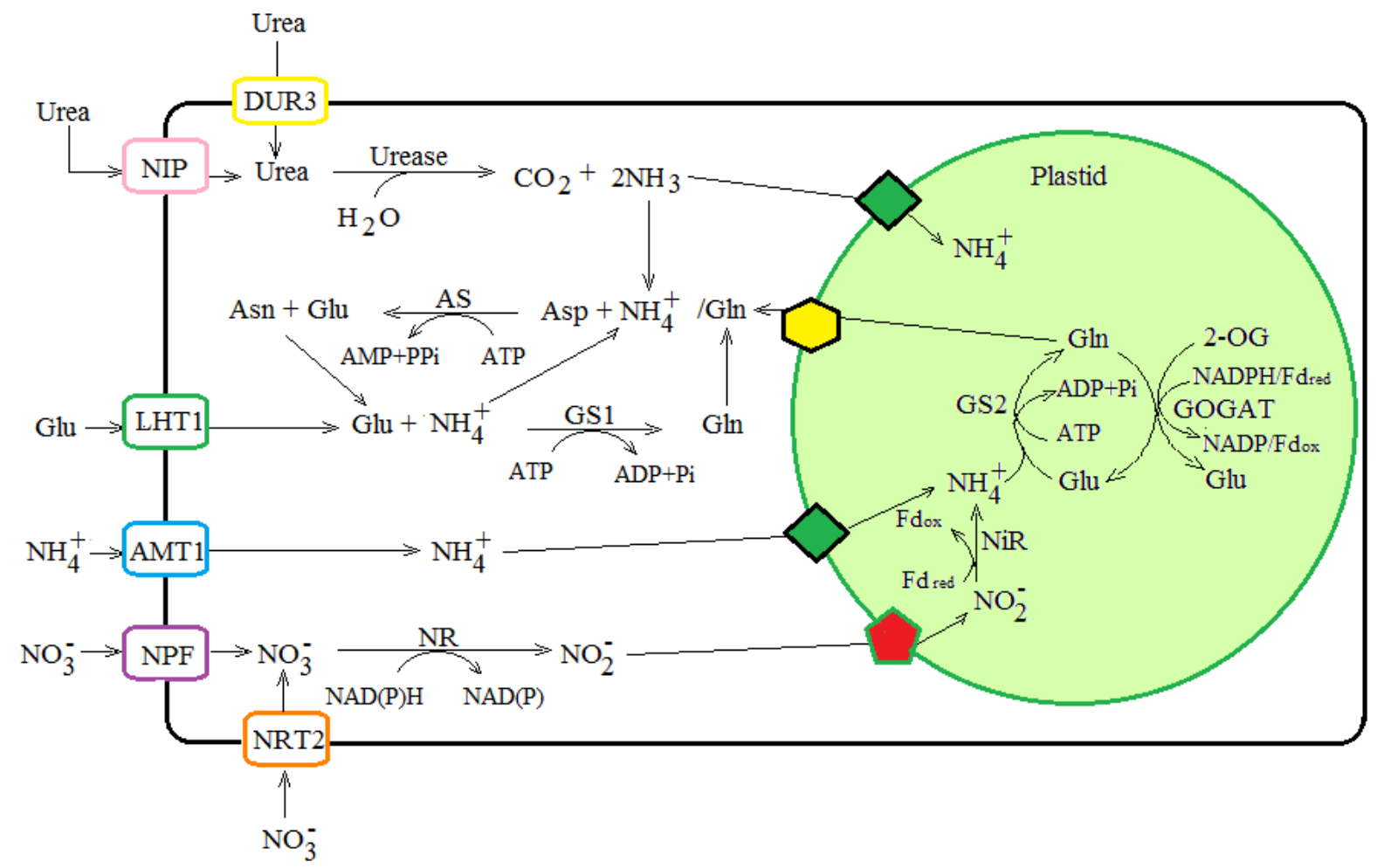

Figure 3. The nitrogen metabolism pathway

Endogenous amino acids such as e.g. alanine and asparagine, are synthesised in single-stage reactions from pyruvate and oxalacetate. Each of them obtains an amino group from 
glutamate in the reaction of transamination, in which pyridoxal phosphate acts as a coenzyme. Asparagine is formed from asparaginate through its amidation.

The rate of amino acid synthesis depends on the number of enzymes and on their activity. Stress to which plant cells are exposed causes an increase in the production of enzymes, which triggers enzymatic defence mechanisms in plants and contributes e.g. to enhanced biosynthesis of endogenous amino acids [23].

Bioactive compounds from trees and shrubs are used in medicine, herbal medicine and cosmetology [24-32]. To date fruits and flowers of exotic trees and shrubs have been primarily used as sources of bioactive compounds. In turn, search for new sources of bioactive compounds is currently focused on native plant species due to its availability. Application of such raw material needs to be based on knowledge of their chemical composition, particularly health-promoting or therapeutic compounds. Research conducted to date on European trees and shrubs has been scarce. This paper presents results of literature studies conducted to systematise knowledge on bioactive compounds found in trees and shrubs native to central Europe.

The aim of this review providing available information on the subject is to indicate gaps in the present knowledge.

\section{Chemical defence of trees and shrubs}

Chemical defence mounted by plants requires considerable energy expenditure, which may have a negative effect on their growth and development. Thus a considerable body of research has been based on the growth-differentiation balance hypothesis and the trade-off principle. According to this approach, differentiation is understood as increased production of secondary metabolites involved in plant defence at the expense of primary metabolites directly related with plant growth and development [33, 34]. In this respect plant species are divided into those characterised by considerable and rapid growth, thus to a limited extent investing in chemical defence, and plants with limited, slow growth, but investing in secondary metabolites at a level ensuring effective protection against pathogens. Typically only one type of compounds predominates in plants: it is alkaloids, phenolic compounds or terpenoids. For example the main defence compounds in oak leaves are condensed tannins [35], while in coniferous trees it is terpenoids [36].

According to the dynamic stress concept, the action of stressors destabilises vital structures and functions of the organism leading to the so-called alarm phase, in which the intensity of vital functions is reduced (stress responses). In this phase if the organism's 
resistance is too low, it may lead to permanent damage. In contrast, at that moment in resistant organisms the resistance phase starts, in which they acquire enhanced resistance to stress factors (overcompensation). Next the organism returns to the normal operating level (adaptation). Plant organisms exposed to permanent stress enter the depletion stage leading to chronic damage.

Pathogen attack is one of the stress factors affecting plants. Among pathogens causing diseases in trees a special role is played by microscopic fungi. Tree seedlings are highly susceptible to fungal infections. They are attacked by fungi from the genera Fusarium, Rhizoctonia and Pythium, which may cause complete seedling dieback. Buds are attacked rarely, while frequent infections affect needles (e.g. needle cast of pine caused by Lophodermium spp.), leaves (e.g. powdery mildew of oak caused by Erysiphe alphitoides) and shoots (e.g. Brunchorstia disease resulting in pine shoot withering, caused e.g. by Gremmeniella abietina (Lagerb.) leading to considerably reduced growth and death of individual trees). Moreover, fruits and seeds may also be infected. The most dangerous infections are root diseases and trunk rot, whereas bark infections, although very frequent and affecting large areas, generally do not pose a significant threat to trees. The most frequent fungal diseases causing losses in stands in Poland include Armillaria root rot, root rot caused by Fomes annosus and needle cast of pine [37-40].

\subsection{Biotic stress}

Studies on plant response to the action of various abiotic and biotic stresses clearly show that that they are processes related to the uncontrolled increase in levels of reactive oxygen species (ROS), also referred to as free radicals, and $\mathrm{H}_{2} \mathrm{O}_{2}$ [41, 42]. When found in excessive amounts they readily enter chemical reactions with cellular components.

During exposure to the action of stressors one of the most important defence mechanisms is connected with the production of chemical compounds. This phenomenon involves two types of mechanisms: non-enzymatic and enzymatic. In the case of the former we observe the action of free radical scavenges, which when reacting with free radicals protect cells against adverse reactions. These include ascorbic acid (vitamin C), A-tocopherol (vitamin E), b-carotene and flavonoids. The former type comprises mechanisms related with the formation of specialised enzymes eliminating free radicals and preventing their formation. The enzymatic system includes superoxide dismutase (SOD E.C.), catalysing dismutation of the superoxide anion radical, and catalase (CAT E.C.), degrading hydrogen peroxide to water [43]. 
The penetration of a pathogen in the plant triggers defence mechanisms connected with the production of secondary metabolites (phytoalexins), defence proteins, i.e. glycine and serine rich proteins, GSRP, being structural components of plant cell walls, pathogenesisrelated proteins (PR) as well as the accumulation of phenols [44-47].

Enhanced biosynthesis of the above-mentioned bioactive compounds is an advantageous side effect of the action of stressors. Trees in their anatomical parts most exposed to the action of pathogens accumulate greatest amounts of bioactive compounds, thanks to which shoots, fruits, leaves, needles and bark have become valuable sources of biologically active compounds.

Available literature on the subject focuses mainly on studies concerning bioactive compounds in plant origin raw materials in terms of their application in herbal medicine, pharmacology and broadly understood health-promoting food. However, these compounds are found in tissues of all plants and they serve similar functions. Increasingly often new reports are being published on the application of various components of trees and shrubs in branches of industry other than the wood industry. This is connected with studies on bioactive compounds in leaves, bark, fruits and essential oils collected from trees, shrubs or their fruit. More valuable woody plants exhibiting health-promoting properties include e.g. Cornelian cherry, also called Cornelian cherry dogwood (Cornus mas L.), hawthorn, black elder, bark of buckthorn as well as common trees such as birch, pine, linden, oak and willow. The presence of bioactive compounds in those plants has contributed to their use in detoxicants, vitamin preparations, preparations enhancing resistance and adjuvant drugs in treatment of various diseases both in the elderly and children [32, 48-52].

\section{Bioactive compounds}

To date literature on the subject has focused on trees of the equatorial and tropical zones, i.e. exotic trees. However, trees of the temperate climatic zone are also rich sources of bioactive compounds such as phenolic compounds, sterols, organic volatile compounds, fatty acids, etc.

\subsection{Phenolic compounds}

Polyphenolics are secondary plant metabolites varying greatly in terms of their structure, molecular mass as well as physical, biological and chemical properties. They are found in all plant parts, i.e. flowers, fruits, seeds, leaves, roots, bark and lignified parts [53, 54]. Phenolic compounds in terms of the structure of the basic carbon skeleton may be divided into phenolic acids, flavonoids, proanthocyanidins and stilbenes [55]. 


\subsubsection{Phenolic acids}

Phenolic acids in their structure contain a hydroxyl and a carboxyl group. Hydroxyl derivatives of benzoic and cinnamic acids are common in the plant world (Figure. 4).<smiles>[R4]c1cc(C(=O)O)c([R])c([R])c1[R3]</smiles>

Hydroxybenzoic acids<smiles>[R4]c1cc(/C=C/C(=O)O)c([R])c([R2])c1[R3]</smiles>

Hydroxycinnamic acids

3-hydroxybenzoic acid
4-hydroxybenzoic acid
salicylic acid
pyrocatechuic acid
genistic acid
$\alpha$-resorcylic acid
$\beta$-resorcylic acid
protocatechuic acid
vanillic acid
isovanillic acid
gallic acid
syringic acid

$\begin{array}{llll}\mathrm{R}_{1} & \mathrm{R}_{2} & \mathrm{R}_{3} & \mathrm{R}_{4} \\ \mathrm{H} & \mathrm{OH} & \mathrm{H} & \mathrm{H} \\ \mathrm{H} & \mathrm{H} & \mathrm{OH} & \mathrm{H} \\ \mathrm{OH} & \mathrm{H} & \mathrm{H} & \mathrm{H} \\ \mathrm{OH} & \mathrm{OH} & \mathrm{H} & \mathrm{H} \\ \mathrm{OH} & \mathrm{H} & \mathrm{H} & \mathrm{OH} \\ \mathrm{H} & \mathrm{OH} & \mathrm{H} & \mathrm{OH} \\ \mathrm{OH} & \mathrm{H} & \mathrm{OH} & \mathrm{H} \\ \mathrm{H} & \mathrm{OH} & \mathrm{OH} & \mathrm{H} \\ \mathrm{H} & \mathrm{OCH}_{3} & \mathrm{OH} & \mathrm{H} \\ \mathrm{H} & \mathrm{OH} & \mathrm{OCH}_{3} & \mathrm{H} \\ \mathrm{H} & \mathrm{OH} & \mathrm{OH} & \mathrm{OH} \\ \mathrm{H} & \mathrm{OH} & \mathrm{OH} & \mathrm{OH}\end{array}$

cinnamic acid

2-coumaric acid

3-coumaric acid

4-coumaric acid

caffeic acid

4-methoxycinnamic acid

3,4-dimethoxycinnamic acid

ferulic acid

isoferulic acid

sinapic acid

$\begin{array}{llll}\mathrm{R}_{1} & \mathrm{R}_{2} & \mathrm{R}_{3} & \mathrm{R}_{4} \\ \mathrm{H} & \mathrm{H} & \mathrm{H} & \mathrm{H} \\ \mathrm{OH} & \mathrm{H} & \mathrm{H} & \mathrm{H} \\ \mathrm{H} & \mathrm{OH} & \mathrm{H} & \mathrm{H} \\ \mathrm{H} & \mathrm{H} & \mathrm{OH} & \mathrm{H} \\ \mathrm{H} & \mathrm{OH} & \mathrm{OH} & \mathrm{H} \\ \mathrm{H} & \mathrm{H} & \mathrm{OCH}_{3} & \mathrm{H} \\ \mathrm{H} & \mathrm{OCH}_{3} \mathrm{OCH}_{3} & \mathrm{H} \\ \mathrm{H} & \mathrm{H} & \mathrm{OH}^{-} & \mathrm{OCH}_{3} \\ \mathrm{H} & \mathrm{H} & \mathrm{OCH}_{3} & \mathrm{OH}^{2} \\ \mathrm{H} & \mathrm{OCH} & \mathrm{OH} & \mathrm{OCH}_{3}\end{array}$

Figure 4 . The structures of phenolic acids $[56,57]$

In plants phenolic acids are mostly found in the bound form as esters and glycosides, contained in lignins and hydrolysed tannins. Examples in this respect may be provided by hydroxycinnamic acids found in ester complexes with carboxylic acids or with glucose. They appear in ester complexes with the following acids: malonic, tartaric, $\alpha$-hydroxy-hydrocaffeic, hydroxycinnamic, tartronic, shikimic, galacturonic, glucaric (as caffeic acid glucuronide), gluconic (as feruloylgluconic acid, which main isomer is 2-O-feruloyl gluconic acid) and 4methoxyaldaric (as 2-O-feruloyl-4-methoxyaldaric acid). In turn, hydroxybenzoic acids are primarily found as glycosides. In plant tissues other complexes of phenolic acids were also identified, e.g. complexes with flavonoids, fatty acids, sterols and polymers of cell walls. Phenolic acids may also be components of anthocyanins or flavones [56, 57]. A separate group is composed of depsides, being a complex of two or more molecules of phenolic acids. In plant organisms, including trees, they are formed mainly in the reaction of the so-called shikimate pathway or malate acid (Figure 1,2) .

Tyrosine and phenylalanine are precursors of most phenolic acids, from which as a result of deamination cinnamic acid and its hydroxy derivatives are formed [58]. 
A particularly interesting active compound from the group of hydroxybenzoic acids is ellagic acid, a dimer of gallic acid, in plants found in the free form and (more frequently) in the ester complex with glucose, forming hydrolysing tannins (ellagotannins) $[59,60]$. It is found in wood of oak, walnut and sweet chestnut, as well as berry fruits, in strawberries and raspberries [61, 62], in the loosestrife family (Lythraceae), particularly pomegranate [24, 35, 42], in certain nut seeds [63] and Muscadine grapes [64]. Ellagic acid exhibits e.g. anti-cancer properties, thanks to which it may inhibit cell division and induce apoptosis in cancer cells $[65,66]$. Moreover, its anti-inflammatory and antioxidant action $[67,68]$ were investigated and confirmed. Ellagic acid found in Cornelian cherry fruit exhibits immunostimulatory, immunomodulatory, antimicrobial, antioxidative and anti-cancer action. It inhibits the adverse effect of UVB radiation, protects skin against degradation and exhibits anti-inflammatory action [69-71]. Ellagic acid is also found in the ester form bound with glucose forming hydrolysing tannins, the so-called ellagitannins.

Salicylic acid, i.e. 2-hydrobexybenzoic acid, which natural source is willow, is another compound of particular interest. Willow bark contains a biologically active substance referred to as salicin [72]. Salicin is $\beta$-glucoside of saligenin [73], which in vivo undergoes two-stage transformation consisting in deglycolisation and oxidation to salicylic acid [74, 75]. Thanks to the rapid development of chemical synthesis in the late 19th century this acid has become a direct precursor of other drugs of similar structure, the so-called salicylates, and non-steroid anti-inflammatory drugs. They include e.g. non-acetylated derivatives of salicylic acid such as sodium salicylate, methyl salicylate, diflunisal, phenyl salicylate (salol), choline salicylate, ethylene glycol salicylate, salicylamide, salsalate, benorylate and diethylamine salicylate [76, 77]. In turn, the acetylated derivative of this acid, i.e. aspirin, is an anti-inflammatory, analgesic, antipyretic and antirheumatic drug. Phenolic acids found in the trees and shrubs are shown in Table 1.

A detailed analysis of metabolism of phenolic compounds synthesised in infected plants showed L-phenylalanine and chorismic acid to be the primary precursors of salicylic acid. These compounds undergo enzymatic transformation to trans-cinnamic acid due to the action of an enzyme, phenylalanine ammonia lyase (PAL), orto-iso-chorismic acid [78].

Table 1. Phenolic acids found in trees and shrubs

\begin{tabular}{|l|l|l|}
\hline \multicolumn{1}{|c|}{ Trees and shrubs } & \multicolumn{1}{|c|}{ Phenolic acids } & Literature \\
\hline $\begin{array}{l}\text { Scots pine Pinus sylvestris } \\
\text { L. }\end{array}$ & Caffeic acid, ferulic acid & {$[79,80]$} \\
\hline
\end{tabular}




\begin{tabular}{|c|c|c|}
\hline Spruce Picea abies H.Karst & $\begin{array}{l}\text { Shikimic acid, galusic acid, } p \text {-coumaric acid, } \\
\text { protocatechuic acid, quinic acid }\end{array}$ & {$[79,81]$} \\
\hline $\begin{array}{l}\text { European beech Fagus } \\
\text { sylvatica } \text { L. - leaves }\end{array}$ & $\begin{array}{l}\text { Caffeic acid, ferulic acid, p-hydroxybenzoic } \\
\text { acid }\end{array}$ & {$[79,82]$} \\
\hline Oak Quercus robus L. & $\begin{array}{l}\text { Ellagic acid, gallic acid, gentisic acid, } p \text { - } \\
\text { hydroxybenzoic acid, protocatechuic acid } \\
\text { syringic acid vanillic acid, p-coumaric acid, } \\
\text { caffeic acid, ferulic acid sinapic acid }\end{array}$ & {$[79,82-85]$} \\
\hline Walnut Juglans regia L. & $\begin{array}{l}\text { Ellagic acid, caffeic acid, p-coumaric acid, } \\
\text { galusic acid }\end{array}$ & {$[79,82]$} \\
\hline Willow Salix spp. & $\begin{array}{l}\text { Ferulic, caffeic, salicylic, vanillic, syringic, } \\
\alpha \text {-resorcylic, m and p-hydroxybenzoic, p- } \\
\text { coumaric, cinnamic acids }\end{array}$ & {$[82,86]$} \\
\hline Salix alba $\mathrm{L}$. & Salicylic and p-coumaric acid & [87] \\
\hline Salix babylonica L. - leaves & Caffeic and p-coumaric acids & {$[88]$} \\
\hline Salix capitata L. - leaves & Protocatechuic acid & {$[89,90]$} \\
\hline $\begin{array}{l}\text { Silver birch Betula pendula } \\
\text { Roth - leaves }\end{array}$ & $\begin{array}{l}\text { Chlorogenic, p-hydroxybenzoic, caffeic, } \\
\text { gallic, coumaric, p-hydroxycinnamic acids }\end{array}$ & {$[82,91]$} \\
\hline Hawthorn Crataegus L. & Chlorogenic, caffeic acid & {$[82,92]$} \\
\hline Rowan Sorbus aucuparia L. & $\begin{array}{l}\text { Neochlorogenic, chlorogenic, protocatechuic, } \\
\text { caffeic and p-hydroxybenzoic acids }\end{array}$ & {$[93]$} \\
\hline $\begin{array}{l}\text { White poplar Populus alba } \\
\text { L. - buds }\end{array}$ & $\begin{array}{l}\text { Benzoic, ferulic, caffeic acids, cinnamic, cis- } \\
p \text {-coumaric and trans-p-coumaric acids }\end{array}$ & {$[82,94]$} \\
\hline Bird cherry Prunus padus L. & Caffeic acid, chlorogenic acids & {$[82]$} \\
\hline
\end{tabular}

Summing up, phenolic acids protects plants against the action of microorganisms and insects, while in combination with polysaccharides they make cell walls more rigid. In the human organism they exhibit diverse biological activity, e.g. scavenging free radicals, chelating metal ions, modifying enzyme activity and protein availability. They prevent cardiovascular disease, cancer and diabetes. Additionally, they protect against photooxidative skin damage 
[95].

\subsubsection{Flavonoids}

The greatest and most diverse group of phenolic compounds found in plants is composed of flavonoids. Chalcone formed via biosynthesis from phenylalanine is a precursor of flavonoids. Synthesis starts with shikimic acid. These compounds are found not only as free molecules, i.e. aglycones, but rather - much more frequently - in the bound form with sugars, i.e. as glycosides. All flavonoids are based on the 2-phenylchromate skeleton, while most types of flavonoids (apart from catechins and anthocyanidins) contain the flavone skeleton, with the ketone group in position 4 (Figure 5) [96, 97].

Chemically all flavonoids are based on the hydrocarbon skeleton of flavone. They differ in the number and type of substituents, while differences between these compounds result primarily from the different structure in only one extreme ring. To date over 7000 various flavonoids have been identified, which in terms of their chemical structure are divided into flavones, flavonols (3-hydroxyflavones), flavanones, flavanols (flavan-3-oles, flavanonoles), anthocyanidins, isoflavones and neoflavonoids (Figure. 5). Thanks to their unique structure flavonoids may protect the cell against reactive oxygen species (ROS) generated in the organism [98, 99].

A<smiles>O=C(/C=C/c1ccccc1)c1ccccc1</smiles>

D<smiles>c1ccc(C2COc3ccccc3C2)cc1</smiles>

G<smiles>O=c1c(-c2ccccc2)coc2ccccc12</smiles>

B<smiles>c1ccc(C2CCc3ccccc3O2)cc1</smiles>

E<smiles>c1ccc(C2CCOc3ccccc32)cc1</smiles>

H<smiles>c1ccc(-c2ccc3ccccc3[o+]2)cc1</smiles><smiles>O=C1CC(c2ccccc2)Oc2ccccc21</smiles><smiles>O=c1cc(-c2ccccc2)oc2ccccc12</smiles><smiles>O=c1cc(-c2ccccc2)c2ccccc2o1</smiles>

Figure 5. Structural formulas of individual flavonoid groups: A. chalcone, a precursor of 
flavonoids; B. flavane; C. flavanones; D. isoflavanes; E. neoflavanes; F. flavones; G. isoflavones; H. flavylium ion; I. neoflavones (nomenclature according to IUPAC).

Table 2. Division of flavonoids depending on their chemical structure [100]

\begin{tabular}{|l|l|}
\hline \multicolumn{1}{|c|}{ Flavonoids } & \multicolumn{1}{|c|}{ Representatives } \\
\hline Flavonol & $\begin{array}{l}\text { (containing solely OH groups) quercetin, kaempferol, myricetin, morin and } \\
\text { others }\end{array}$ \\
\hline Flavone & (containing also CHO groups): luteolin, apigenin \\
\hline Flavonone & flavonones: (containing C=O groups): hesperidin, naringenin, eriodictyol \\
\hline Flavan-3-ol & catechin, theaflavin and derivatives \\
\hline Isoflavones & daidzein, genistein, glycitein \\
\hline Anthocyanidin & $\begin{array}{l}\text { anthocyanins: cyanidin, delphinidin, malvidin, pelargonidin, peonidin, } \\
\text { petunidin, neoflavonoids (4-phenylcoumarin or 4-phenylchromen-2-one): } \\
\text { dalbergin, dalbergichromene, nivetin }\end{array}$ \\
\hline
\end{tabular}

Flavonoids are phytoalexins, i.e. substances serving protective functions, formed as a result of the plant's contact with a pathogen, frequently inducing expression of several genes encoding enzymes of the phenolic biosynthesis pathway [101]. Isoflavonoids are highly toxic towards fungal pathogens, which is particularly evident in such compounds as pterocarpanes, isoflavanes, isoflavones and isoflavonones. The mechanism of their action consists in the inhibition of spore development and mycelium growth as well as the damage of fungal cell membrane structure [102-104].

Flavonoids are extensively used in woody plants of our climatic zone. They are found in the bark of common oak Quercus robur Linne, sessile oak Quercus petrea Lieblein or downy oak Quercus pubescens Willdenow = Quercus lanuginosa Thuillier., in inflorescences of hawthorn (Inflorescentia Crataegi), leaves of birch (Betulae Folium), flowers of elderberry (Sambuci flos), as well as linden inflorescences (Table 3). Flavonoids introduced to the human organism may serve a similar role as vitamins. They seal blood vessel walls, as well as exhibit antiviral, antibacterial and antifungal action [105], while in oral medicine flavonoids show considerable efficacy in prevention of periodontitis. An inhibitory effect of flavonoids on cancer cell growth was also observed [106-109].

Table 3 Flavonoids found in trees and shrubs 


\begin{tabular}{|c|c|c|}
\hline Tree and shrub species & Flavonoids & Literature \\
\hline $\begin{array}{l}\text { Scots pine Pinus sylvestris L. } \\
\text { needles }\end{array}$ & $\begin{array}{l}\text { Prodelphinidin and lacks taxifolin, quercetin and } \\
\text { taxifolin } \\
\text { taxifolin, taxifolin } 3^{\prime} \text {-O-glucoside, quercetin as } \\
\text { well as quercetin } 3 \text {-O-glucoside and } 3^{\prime} \text {-O- } \\
\text { glucoside }\end{array}$ & $\begin{array}{l}{[82,110]} \\
{[111]}\end{array}$ \\
\hline Oak Quercus robus L. & $\begin{array}{l}\text { Tannins - derivatives of pirocatechin and } \\
\text { pyrogallol, epikatechina } \\
\text { flawan-3-oli, katechina, quercetin }\end{array}$ & {$[79,112,113]$} \\
\hline $\begin{array}{l}\text { European beech Fagus } \\
\text { sylvatica } \text { L. - leaves }\end{array}$ & $\begin{array}{l}\text { Catechin,kempferol, gallocatechin, kaempferol 3- } \\
\text { glucoside, naringenin, quercetin, quercetin-3- } \\
\text { glucoside, mirycetyna, quercetin, taxifolin }\end{array}$ & {$[79,82]$} \\
\hline $\begin{array}{l}\text { Spruce Picea abies H. Karst } \\
\text { - needle }\end{array}$ & $\begin{array}{l}\text { Catechin, kaempferol, kaempferol } 3 \text {-glucoside, } \\
\text { naringenin, quercetin, quercetin } 3 \text {-glucoside, } \\
\text { quercitrin }\end{array}$ & {$[79,82]$} \\
\hline Salix purpurea $\mathrm{L}$. & $\begin{array}{l}\text { Salipuroside, isosalipuroside. naringenin, } \\
\text { naringenin 5-O-glucoside, naringenin 7-O- } \\
\text { glucoside, chalcone isosalipurposide, flavan-3-ol, } \\
\text { catechina }\end{array}$ & {$[114,115]$} \\
\hline $\begin{array}{l}\text { Salix spp: } \\
\text { S. alba } \\
\text { S. viminalis }\end{array}$ & $\begin{array}{l}\text { Amentoflavone, isoquercetin, quercetin, rutin, } \\
\text { quercimeritrin, apigenin, 3-O-glucoside } \\
\text { rhamnasine, izosalipurpurozyd, hiperozyd, } \\
\text { catechin naringenin, luteolin, eriodycerol, } \\
\text { naringin, kaempferol, apigenin-7-O-glucoside, } \\
\text { astralgin, quercimeritrin and quercetin-3,7-di-O- } \\
\text { glucoside }\end{array}$ & $\begin{array}{l}{\left[\begin{array}{l}79, \quad 88, \\
116-120]\end{array}\right.} \\
\end{array}$ \\
\hline Hawthorn Crataegus L. & $\begin{array}{l}\text { Catechin, epicatechin, hyperoside, } \\
\text { witexin, } \quad \text { isovitexin, } \\
\text { rutin and kemferol }\end{array}$ & {$[79,82,121]$} \\
\hline Black elder Sambucus nigra & rutin, quercetin, astragalin and isoquercetin & {$[79,82,122$,} \\
\hline
\end{tabular}




\begin{tabular}{|l|l|l|} 
L. - flowers & & $123]$ \\
\hline Birch - leaves & $\begin{array}{l}\text { hyperoside, myricetin and luteolin, catechin } \\
\text { tannins }\end{array}$ & {$[79,82,124]$} \\
\hline Rowan Sorbus aucuparia L. & $\begin{array}{l}\text { quercetin, rutin, hyperoside, isoquercetin and } \\
\text { quercetin-3-O-sophoroside }\end{array}$ & {$[125]$} \\
\hline $\begin{array}{l}\text { Common yew Taxus baccata } \\
\text { L. }\end{array}$ & $\begin{array}{l}\text { 3-O-rutinosides quercetin, myricetin, kaempferol, } \\
\text { 7-O-glucosides [126] }\end{array}$ \\
\hline $\begin{array}{l}\text { Black locust Robinia } \\
\text { pseudoacacia L. }\end{array}$ & $\begin{array}{l}\text { dihydrorobinetin butein } \\
\text { dihydromyricetin, fisetin, fustin, isoliquiritigenin, } \\
\text { myricetin liquiritigenin }\end{array}$ & {$[127]$} \\
\hline
\end{tabular}

\subsubsection{Anthocyanins}

Anthocyanins constitute another class of the discussed compounds. They are the largest group of water soluble phytopigments widely distributed in the plant kingdom. They are mainly found in flowers and fruits providing them with colour, while they are also contained in seeds, leaves, stems and roots. The chemical structure of anthocyanins is based on the anthocyanidin skeleton, to which various substituents are attached (Figure 6). Most proantocyanidins are compounds containing in their structure epicatechin units, referred to as procyanidins [128]. The polyphenol structure and numerous -OH groups in proanthocyanidin molecules are responsible for their high antioxidant activity. Chemically anthocyanins are glycosides; glycosilation makes them more stable and more water soluble. These polyphenols are also found in the non-glycosiled form (aglycones) as anthocyanidins. The presence of various chemical groups as substituents determines the considerable biological activity of these compounds, including anti-inflammatory, antioxidant, antibacterial or even anti-cancer activity. These compounds are found in such vegetables as beets, red cabbage, red onion, radish, red lettuce and almost all fruits, primarily berries, in their skin and flesh. An example may here be provided also by pelargonidin present in the skin of radish and potatoes, or derivatives of delphinidin found in aubergine skin [128]. Proanthocyanidins (also called condensed or non-hydrolysing tannins) are also found in leaves, lignified parts of plants, as well as flowers and fruits [129]. Inflorescences of hawthorn (Crataegi inflorescentia, Crataegus sp. Rosaceae) are a well-known source of proanthocyanidin used in herbal medicine for years $[130,131]$. Recently intensive studies 
have been conducted on the extract from bark of maritime pine Pinus pinaster (Pinaceae), patented as Pycnogenol, which proanthocyanidin content is $85 \%$. This preparation exhibits e.g. strong antioxidant properties (Table 4) [132, 133].

A considerable body of data indicates that a diet rich in anthocyanins plays a significant role in the prevention of cardiovascular disease and cancer [134]. It was shown that plant extracts rich in anthocyanins may exert a protective effect on the function of blood vessel walls, preventing endothelium dysfunction and loss of its regulatory activity [135, 136]. Antioxidant properties of these compounds may be used in the prevention of cancer both of the alimentary tract and internal organs [137]. They also prevent oxidation of the LDL cholesterol fraction [138].<smiles>[R]c1cc2c([R5])c([R6])c([R7])cc2[o+]c1-c1cc([R])c([R7])c([R5])c1</smiles>

Figure. 6 The basic structure of anthocyanidins, aglycone components of anthocyanins. The numbers of the carbon skeleton and the position of naturally found substituents $\left(\mathrm{R}^{\mathrm{x}}=\mathrm{H}, \mathrm{OH}\right.$, $\left.\mathrm{OCH}_{3}\right)$ [139]

Table 4 Proanthocyanidins found in trees and shrubs

\begin{tabular}{|l|l|l|}
\hline \multicolumn{1}{|c|}{ Tree and shrub species } & \multicolumn{1}{|c|}{ Proanthocyanidins } & Literature \\
\hline $\begin{array}{l}\text { Scots pine Pinus sylvestris L. } \\
\text { Pinus densiflora } \text { L. needles }\end{array}$ & $\begin{array}{l}\text { Proanthocyanidins (OPC) procyanidins, } \\
\text { prodelphinidins and propelargonidins } \\
\text { catechin derivatives, both dimers and } \\
\text { trimers. }\end{array}$ & {$[140-143]$} \\
\hline Quercus petraea L. and Q. robur & Proanthocyanidins & {$[144-146]$} \\
\hline Hawthorn Crataegus oxyacantha L. & Procyanidin glycosides & {$[92,147,148]$} \\
\hline Bird cherry Prunus padus & $\begin{array}{l}\text { Cyanidin-3-rutinoside and cyaniding-3- } \\
\text { glucoside }\end{array}$ & {$[149]$} \\
\hline Salix purpurea L. & $\begin{array}{l}\text { Cyanidin-3-glucoside, } \\
\text { (delphinidin-3-glucoside) }\end{array}$ & {$[150]$} \\
\hline
\end{tabular}




\subsubsection{Stilbenes}

Stilbenes are metabolites of the phenylpropanoid pathway activated under biotic and abiotic stress. They are compounds with the 1,2-diphenylethylene skeleton. Only some, unrelated plant species are capable of synthesising and accumulating stilbenes. The enzyme facilitating this synthesis of stilbene synthase (STS). In plants stilbenes serve several functions, among which the most significant is related to strong antimicrobial properties, thus they are classified as phytoalexins [151]. Other known functions include also their repellent action against herbivores as well as allelopathic and antioxidant properties. Stilbenes are produced in small amounts; however, biosynthesis is activated primarily post-infection, while it is also triggered by wounding, UV radiation, ozone and aluminum ions. Resveratrol (3,5,4'trihydroxy-trans-stilbene) is one of the most extensively described stilbenes [152].

a)

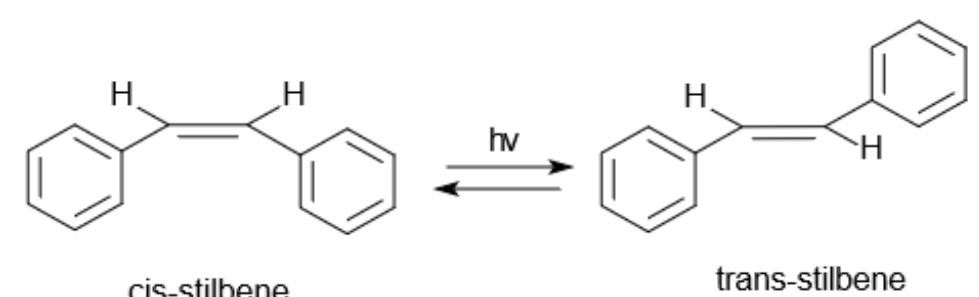

b)

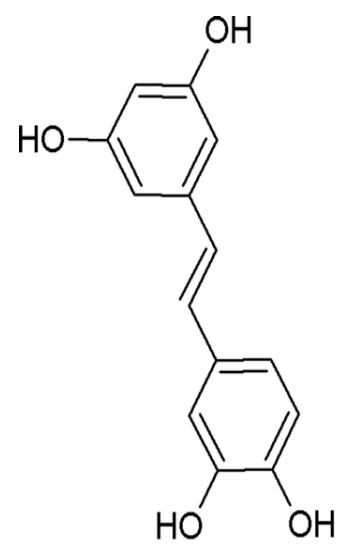

piceatannol

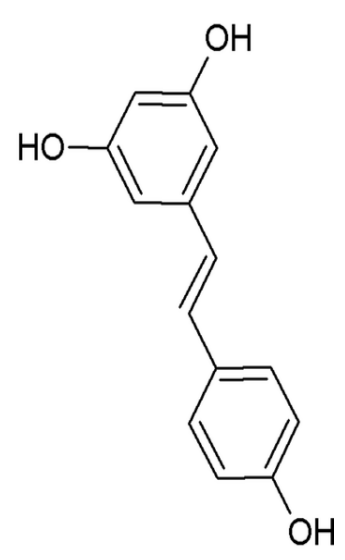

resveratrol

Figure. 7. The chemical structure of stilbenes: a) cis and trans b) piceatannol and resveratrol [153].

Resveratrol is found in the form of two isomeric forms: cis- and trans- (Figure 7). Transresveratrol is a phenol stilbene found in many plants, e.g. the grape family (Vitaceae), particularly common grape vine (Vitis vinifera). The other form of resveratrol, i.e. cis-, is formed as a result of isomerisation of trans-resveratrol and after decomposition of resveratrol 
polymer molecules during fermentation of grape skins, due to the action of UV radiation and at high pH [154]. Resveratrol was first isolated in 1940 from roots of Veratum gradiflorum [155]. Its highest concentration was recorded in roots of Japanese knotweed (Polygonum cuspidatum). In folk medicine this plant was successfully used to treat pyoderma, mycoses and venereal diseases [156]. Moreover, resveratrol has been applied in cancer prevention and treatment thanks to its ability to effectively inhibit each stage of neoplasia, i.e. initiation, promotion and progression of the disease [157].

Stilbenes are secondary metabolites relatively rarely found in nature. To date they have been reported in almost 70 unrelated plant species belonging to approx. 30 genera and 12 families. The greatest stilbene contents are detected in plants from the pine family (Pinaceae), the grape family (Vitaceae), the beech family (Fagaceae), the mulberry family (Moraceae) and the grass family (Poaceae) [151].

Table 5 Stilbenes found in trees and shrubs

\begin{tabular}{|l|l|l|}
\hline \multicolumn{1}{|c|}{ Tree and shrub species } & \multicolumn{1}{|c|}{ Stilbenes } & \multicolumn{1}{c|}{ Literature } \\
\hline $\begin{array}{l}\text { Scots pine - Pinus sylvestris L. } \\
\text { Eastern white pine - Pinus strobus } \\
\text { Japanese red pine - Pinus densiflora }\end{array}$ & $\begin{array}{l}\text { Pinosylvin, pinosylvin 3-o-methyl } \\
\text { ether }\end{array}$ & [158-160] \\
\hline Spruce Picea abies L. H.Karst & $\begin{array}{l}\text { Cis and trans- astringin, trans- } \\
\text { piceatannol, cis- and trans-piceid, } \\
\text { trans-resveratrol }\end{array}$ & {$[159,161-164]$} \\
\hline Black locust Robinia pseudoacacia L. & Piceatannol and resveratrol & {$[165]$} \\
\hline Morus spp. Mulberry & Resveratrol & {$[166]$} \\
\hline
\end{tabular}

For economic reasons the durability and resistance of softwood has been of considerable interest for many decades. In the 1980's and 1990's it was definitely shown that it is stilbenes that protect wood against pathogens [167]. It was confirmed in vitro that both pinosylvin and pinosylvin 3-O-methyl ether are very strong inhibitors of two main wood degrading fungi, i.e. Coriolus versicolor and Gloephyllum trabeum [168]. Additionally, also some nematode-resistant pine species in their bark and heartwood contain nematicidal compounds, among which pinolsylvin 3-O-methyl ether proved to be the most effective [169].

\subsection{Sterols}

Sterols constitute another group of compounds found in trees. They are widely distributed in the plant world. These compounds are classified as lipids, specifically to the 
non-saponifying fraction. Sterols are an important component of biological membranes. The nonpolar, hydrophobic part of the sterol molecule, by attaching to fatty acids of phospholipids, contributes to a reduction of membrane fluidity [170]. Sterols are organic chemical compounds, alcohols belonging to the group of steroids. They are formed by formal substitution of the carbon atom in position 3 in the steroid skeleton by the hydroxyl group. Phytosterols include sterols (unsaturated compounds) and stanols (saturated compounds). Phytosterols are chemical homologues of cholesterol differing in the saturation rate and chain configuration. Basic plant sterols found in vegetable oils differ in the structure of their side chain (Figure 8). Depending on their structure and biosynthesis, plant sterols were divided into the following groups: 4-dimethylsterols, $4 \alpha$-monomethylsterols and 4,4-dimethylsterols, 4-dimethylsterols, including stigmasterol, $\beta$-sitosterol and campesterol, are most common plant sterols. Phytosterols are natural plant components, e.g. in soy, vegetable oils, rice and pine wood. They are also found in small amounts in nuts, vegetables and fruit. Research results indicate that certain lipid components such as polyunsaturated fatty acids, sterols and plant stanols may effectively lower blood cholesterol level. The content of the LDL cholesterol fraction is reduced not only by unrefined sterols, but also those subjected to hydrogenation or esterification. To date almost 40 forms of plant sterols have been identified, among which $\beta$-sitosterol, campesterol and stigmasterol are most common [171-173]. The most abundant source of phytosterols is presently provided by tall oil (the name originates from Finnish "tallolie", meaning pine oil), which is obtained as a result of wood conversion in the process of cellulose production.

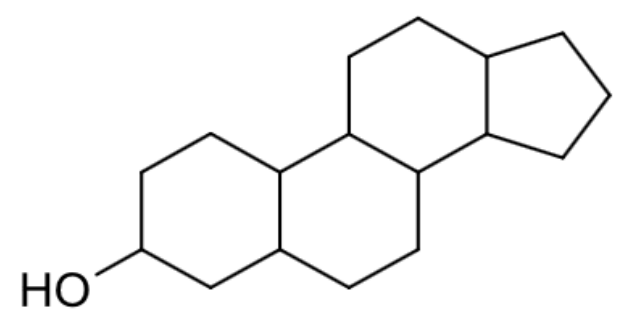

Figure 8. The sterol skeleton [170]

Table 6 Sterols found in trees and shrubs

Trees and shrubs Sterols Literature 


\begin{tabular}{|c|c|c|}
\hline $\begin{array}{l}\text { Silver birch Betula pendula } \\
\text { Roth L., Scots pine Pinus } \\
\text { sylvestris L., Black locust } \\
\text { Robinia pseudoacacia L. }\end{array}$ & $\begin{array}{l}\text { Free sterols: } \beta \text {-sitosterol, } \beta \text {-sitostanol } \\
\text { (stigmastanol), campesterol } \\
\text { Esterified sterols: } \beta \text {-sitosterol, } \beta \text {-sitostanol } \\
\text { (stigmastanol), campesterol, } \alpha \text {-sitosterol, } \\
\text { Cycloartenol, } 24 \text {-methylenecycloartanol, } \\
\text { squalene, betulaprenol-6, betulaprenol-7, } \\
\text { betulaprenol-8, lupeol }\end{array}$ & {$[174-180]$} \\
\hline $\begin{array}{l}\text { Hawthorn fruits Crataegus } \\
\text { L. }\end{array}$ & Stigmasterol, kaempesterol, $\beta$-sitosterol & [181] \\
\hline
\end{tabular}

\subsection{Volatile compounds}

Another group of plant origin active compounds comprises essential oils. They are volatile compounds most frequently found in special cells of secretory tissues of plants. These compounds are natural isoprene oligomers widely found in nature. Chemically they are complex, multicomponent mixtures of monoterpene and sesquiterpene compounds and their derivatives, including aromatic derivatives. These substances may be alcohols, ketones, aldehydes, esters or ethers. They occasionally contain also nitrogen or sulphur compounds. Their distinguishing characteristic is connected with the fact that one essential oil may contain more than ten or even several dozen compounds differing in their concentrations and properties [182,183]. Plants are considered as sources of essential oils if they contain over $0.01 \%$ oil. Essential oils are obtained from trees and shrubs from the family Pinaceae (genera Pinus, Abies, Picea, Larix) (Table 7). Pine oil exhibits antiseptic activity, it alleviates symptoms of the common cold, flu, tonsillitis, sinusitis, rhinitis and cough, while it also stimulates the circulatory system. Fir oil next to its expectorant and antiseptic action shows diuretic and antirheumatic action, whereas studies have confirmed that terpenes present in birch oil exhibit anti-inflammatory, anticancer, antibacterial and antiviral activity.

Table 7. Essential oils found in trees and shrubs

\begin{tabular}{|l|l|l|}
\hline \multicolumn{1}{|c|}{ Trees and shrubs } & \multicolumn{1}{|c|}{ Essential oil } & Literature \\
\hline $\begin{array}{l}\text { Norway spruce } \\
\text { Picea abies L., H. Karst }\end{array}$ & $\begin{array}{l}\text { Spruce composition: camphor, limonene, } \\
\text { camphene, borneol, } \alpha \text { - and } \beta \text {-pinene }\end{array}$ & {$[184,185]$} \\
\hline Scots pine Pinus sylvestris L. & $\begin{array}{l}\text { Pine composition: pinenes, carenes, } \\
\text { cadidene, (S)-(-)-limonene }\end{array}$ & {$[186,187]$} \\
\hline
\end{tabular}




\begin{tabular}{|c|c|c|}
\hline $\begin{array}{l}\text { Black locust Robinia } \\
\text { pseudoacacia } \mathrm{L} .\end{array}$ & $\begin{array}{l}\text { Flower extract: monoterpenes including } \\
\text { linalool, geraniol, terpinen-4-ol and } \alpha- \\
\text { terpineol, cis- and trans-farnesol, nerolidol } \\
\text { and } \beta \text {-bisabolol }\end{array}$ & [188] \\
\hline $\begin{array}{l}\text { Silver birch Betula pendula } \\
\text { Roth }\end{array}$ & $\begin{array}{l}\text { Birch composition: betuline, betulinic } \\
\text { acid, betulin aldehyde, oleanolic acid }\end{array}$ & [189] \\
\hline $\begin{array}{l}\text { European siver fir Abies alba } \\
\text { Mill. }\end{array}$ & $\begin{array}{l}\text { Fir needle oil composition: santene, L- } \alpha \\
\text { limonene, L-bornyl acetate, lauric } \\
\text { aldehyde }\end{array}$ & [190-191] \\
\hline Juniper Juniperus communis L. & $\begin{array}{l}\alpha \text {-Pinene, camphene, limonene, cadinene, } \\
\text { terpinen- } 4 \text {-ol, myrcene, } \beta \text {-pinene, sabinene }\end{array}$ & [192-195] \\
\hline
\end{tabular}

Presented literature sources indicate that active substances of plant origin, particularly those obtained from trees and shrubs growing in the temperate climate zone, exhibit a beneficial effect on human health. Thanks to the presence of bioactive compounds in those plants they have found applications as detoxicants, vitamin supplements, as well as preparations boosting immunity and adjunctive medication in treatment of various diseases. These is a considerable body of data indicating that the diet rich in bioactive compounds plays a significant role in prevention of cardiovascular diseases and cancer. In view of the fact that treatment of chronic pain, cancer, cardiovascular disease and a number of other diseases requires a combination of several therapeutic methods, alternative therapies using plant origin preparations are gaining popularity. It also needs to be stressed that molecular mechanisms of action in the case of active substances contained in plant preparations have not been fully elucidated and require further research.

The review of literature presented in this paper presents the potential of trees and shrubs native to the temperate zone as sources of bioactive compounds.

Author Contributions: Lidia Szwajkowska-Michałek and Kinga Stuper-Szablewska designed and conducted the text; all authors contributed to the manuscript preparation according to the professional experience.

Conflicts of Interest: There is no conflict of interest.

\section{References}

\section{References}

1. Kaplan, I.; Halitschke, R.; Kessler, A.; Sardanelli, S.; Denno, R.F. Constitutive and induced defenses to herbivory in above- and belowground plant tissues. Ecology 2008, 89,2, $392-406$. 
2. Carmona, D.; Lajeunesse, M.J.; Johnson, T.J. Plant traits that predict resistance to herbivores. Funct Ecol 2011, 25, 358-367.

3. Rayner, A.D.M.; Boddy, L. Fungal decomposition of wood - its biology and ecology; John Wiley and Sons. Chichester, New York, Brisbane, Toronto, Singapore, 1-428, 1988.

4. Kozłowska, M. Phenolic composition of red raspberry canes in relation to Didymella applanata (Niessl) Sacc. response. Acta Physiol Plant 1994, 16 (3), 211-215.

5. Evensen, P.C.; Solheim, H.; Høiland, K.; Stenersen, J. Induced resistance of Norway spruce, variation of phenolic compounds and their effects of fungal pathogens. Forest Pathol 2000, 30, 97-108.

6. Przybył, K.; Karolewski, P.; Oleksyn, J.; Labędzki, A.; Reich, P.B. Fungal diversity of Norway spruce litter: effects of site conditions and premature leaf fall caused by bark beetle outbreak. Microb Ecol 2008, 56, 332-340.

7. Scalbert, A. Antimicrobial properties of tannins. Phytochemistry 1991, 30, 3875-3883.

8. Cowan, M.M. Plant Products as Antimicrobial Agents. Clin. Microbiol. Rev., 1999, 12, 4, $564-582$.

9. Harborne, J.B.. The comparative biochemistry of phytoalexins induction in plants. Biochem. System Ecol. 1999, 27, 335-367.

10. Leszczyński, B. Rola allelozwiązków w oddziaływaniach owady - rośliny. In: Biochemiczne oddziaływania środowiskowe [Biochemical environmental interactions] (Oleszek,W., Głowniak K., Leszczyński B., Eds.), Akademia Medyczna, Lublin, Poland, 2001; pp. 61-85.

11. Malinowski, H. Strategie obronne roślin drzewiastych przed szkodliwymi owadami. Defensive strategies of woody plants against harmful insects. Leś. Pr. Bad./For. Res. Pap, 2008, Vol. 69, 2, 165-173.

12. Buhaescu, I.; Izzedine, H. Mevalonate pathway: areview of clinical and therapeutical implications. Clin Biochem, 2007, 40, 575-584.

13. Kohlmünzer, S. Farmakognozja. PZWL, Warszawa, 1998; pp. 670.

14. Kopcewicz, J.; Lewak, S. Fizjologia roślin. PWN, Warszawa, 2002; pp.361-86.

15. Mevalonate Pathway of Eukaryotes and Archaea (Biochemistry).svg, https://en.wikipedia.org/wiki/Mevalonate_pathway (13.06.2019).

16. Herrmann, K. M. The Shikimate Pathway: Early Steps in the Biosynthesis of Aromatic Compounds Plant Cell, 1995, 7, 907-919.

17. Schmid, J.; Amrhein, N. Molecular organization of the shikimate pathway in higher plants. Phytochemistry, 1995, 39,737-749. 
18. Masclaux-Daubresse, C.; Daniel-Vedele, F.; Dechorgnat, J.; Chardon, F.; Gaufichon, L.; Suzuki, A. Nitrogen uptake, assimilation and remobilization in plants: challenges for sustainable and productive agriculture. Ann Bot. 2010,105,1141-1157.

19. Krupp, A. Plant nitrogen assimilation and its regulation: a complex puzzle with missing pieces. Curr Opin Plant Biol., 2015, 25, 115-122.

20. Witte, C.P. Urea metabolism in plants. Plant Sci. 2011,180, 431-438.

21. Pinton, R.; Tomasi, N.; Zanin, L. Molecular and physiological interactions of urea and nitrate uptake in plants. Plant Signal Behav. 2016,11, 1076603.

22. Zboińska, M. W jaki sposób rośliny pobierają i asymilują azot? [How plants uptake and assimilate nitrogen?] Edukacja biologiczna i środowiskowa 2018, 2, 19-31.

23. Berg, J. M.; Tymoczko J.L.; Stryer L. Biochemia Warszawa PWN 2009

24. Blumenthal, M.; Goldberg, A. Brinckann, J. Herbal Medicine. Expanded Commission E Monographs. Pine Needle Oil. 1st ed. American Botanical Council. Newton 2000:3046.

25.Chrubasik S, Eisenberg E, Balan E, Weiberger T, Luzzati R, Conradt C. Treatment of low back pain exacerbations with willow bark extract: a randomized double-blind study. Am. J. Med. 2000; 109,9-14.

26. Akao T, Yoshino T, Kobashi K, Hattori M. Evaluation of salicin as an antipyretic prodrug that does not cause gastric injury. Planta Med. 2002; 68, 714-718.

27. Różański H.: Naturalne alternatywy dla antybiotykowych stymulatorów wzrostu i kokcydiostatyków. LNB Poland, Stryków 2005. Konferencja Naukowa.

28. Różański H: Woski w dawnych i współczesnych kosmetykach naturalnych. Kosmetyka 2008, 1(3), 62-64.

29. Nowak, G.; Nawrot, J. Surowce roślinne i związki naturalne stosowane w chorobach układu oddechowego. Herba Pol. 2009, 55-4.

30. Czyż K., Surowce kosmetyków naturalnych, czyli ile natury w produktach organicznych cz. II, Przem kosm, 2010,1, 10-11.

31. Ratz-Łyko A., Składniki aktywne pochodzenia naturalnego w kosmetykach anti-age, Cosmetology Today: Patents and movention, 2013, 3, 10-11.

32. Dyduch J. Bez czarny - charakterystyka biologiczna, wykorzystanie w ziołolecznictwie, kosmetyce i gospodarstwach domowych. Episteme, 2014, 25, 21-27.

33. Agraval A. A. Macroevolution of plant defense strategies. Trends in Ecology and Evolution, 2006, 22, 2,103-109.

34. Barton K. E., Koricheva J. The ontogeny of plant defense and herbivory: Characterizing 23 
general patterns using meta-analysis. American Naturalist, 2010, 175, 4, 481-493.

35. Forkner, R.E.; Marquis, R.J.; Lill, J.T. Feeny revisited: condensed tannins asanti-herbivore defences in leaf-chewing herbivore communities of Quercus. Ecol. Entomol., 2004, 29, 174-187.

36. Manninen, A.M.; Vuorinen, M.; Holopainen, J. K.. Variation in growth, chemical defense, and herbivore resistance in Scots pine provenances. J Chem Ecol, 1998, 24 (8), 1315-1331.

37. Sierota Z. Choroby infekcyjne w drzewostanach gospodarczych - przyczyny i przebieg w okresie ostatniego dwudziestolecia. [In]: Mańka M. [ed.]. Choroby Roślin a Środowisko. PTFit. Poznań. 1996, 59-66.

38. Sierota, Z. Gdy las Choruje[When the Forest IsI 11]; Centrum Informacyjne Lasów

Państwowych: Warszawa, Poland, 2011.

39. Łakomy, P. The first record of Armillaria mellea sensu stricto in a forest ecosystem in Poland. Phytothol. Pol. 2000, 21, 155-163.

40. Mańka, K. Fitopatologia leśna [Forest Pathology]. PWRiL Warszawa 2005[in Polish].

41. Apel, K.; Hirt, H. Reactive oxygen species: metabolism, oxidative stress, and signal transduction. Ann Rev Plant Biol, 2004, 55, 373- 399.

42, Jaspers, P.; Kangasjarvi, J. Reactive oxygen species in abiotic stress signaling. Physiol Plant 2010, 138,405-413

43. Vertuani, S.; Angusti, A.; Manfredini, S. The antioxidants and pro-antioxidants network:an overview. Curr. Pharm. Des., 2004, 14, 1677-94.

44.Darvill A.G.; Albersheim P. Phytoalexins and their elicitors - a defense against microbial infection in plants. Ann Rev Plant Physiol 1984; 35: 243-275.

45. Van Loon L.C. Pathogenesis-related proteins. Plant Mol Biol 1985, 4, 111-116

46. Carr, J.P.; Klessig, D.F. The pathogenesis-related proteins of plants. In JK Setlow, ed, Genetic Engineering: Principle and Methods, Vol 11. Plenum Press, New York, pp 65109, 1989.

47. Dixon, R.A.; Harrison, M.J.; Lamb C.J. Early events in the activation of plant defense responses. Annu Rev Phytopathol, 1994; 32, 479-501.

48. Hartwell, J.L. Plants used against Cancer. A survey. Lloydia 30, 379-436 (1967);

49.Strzelecka H., Kowalski J. (red.), Encyklopedia zielarstwa i ziołolecznictwa, Wydawnictwo Naukowe PWN 2000

50. Cis J, Nowak G. Ziołowa apteka - układ oddechowy. W: Zioła z apteki natury. Poznań 2006, $222-7$. 
51.Kołodziej, Barbara, ed. Uprawa ziót: poradnik dla plantatorów. Państwowe Wydawnictwo Rolnicze i Leśne, 2010.

52. Nowak, G.; Nawrot, J. Surowce roślinne i związki naturalne stosowane w chorobach układu oddechowego. Herba Polonika 2009, 50, 4.

53.Hermann, K.,. Review on nonessential constituents of vegetables. III. Carrots, celery, parsnips, beets, spinach, lettuce, endives, chicory, rhubarb, and artichokes. Lebensm. Unters. Forsch. 1978, 167, 262-273.

54.Kolesnikov, M.P.; Gins, V.K. Prikl. Biokhim. Mikrobiol., 2001, vol. 37, no. 5, pp. 616620.

55. Blomhoff, R.; Role of dietary phytochemicals in oxidative stress. In: Bernhoft A (ed) Bioactive compounds in plants - benefits and risks for man and animals. Proceedings from a symposium held in Norwegian Academy of Science and Letters, Oslo, 13-14 November 2008. Novus Forlag, Oslo

56.Robbins, R.J. Phenolic acids in foods: An overview of analytical methodology. J. Agric. Food. Chem., 2003, 51, 10, 2866-2887.

57.Jeszka, M.; Flaczek, E.; Kobus-Cisowska. J. et al. Związki fenolowe - charakterystyka i znaczenie w technologii żywności. Nauka Przyr Technol, 2010, 4, 2, 1-13.

58. Castellucio, C.; Paganga, G.; Melikan, N.; Bowell, G.P.; Pridham, J.; Sampson, J.; RiceEvans, C. Antioxidant potential of intermediates in phenylopropanoid metabolism in higher plants. FEBS Letter, 1995, 368.

59.Quideau, S.; Feldman, K.S. Ellagotannin chemistry: The first synthesis of dehydrohexahydroxydiphenoate (DHHDP) esters from oxidative coupling of unetherified methyl gallate. J Org Chem 1997, 62, 8809-8813.

60.Scalbert, A.; Williamson, G. Dietary intake and bioavailability of polyphenols. J Nutr 2000, 130, 2073-2085.

61.Häkkinen, S.H.; Törrönen, A.R. Content of flavonols and selected phenolic acids in strawberries and Vaccinium species: influence of cultivar, cultivation site and technique. Food Res. Int., 2000, 33, 517-524.

62.Wang, S.; Lin, H.S. Antioxidant activity in fruits and leaves of blackberry, raspberry and strawberry varies with cultivar and developmental stage. J Agric Food Chem 2000, 48, 2,140-146.

63.Aguilera-Carbo, A.F.; Augur, C.; Prado-Barragan, L.A.; Aguilar, C.N.; Favela-Torres, E. Extraction and analysis of ellagic acid from novel complex sources. Chem. Pap. 2008, $62,4,440-444$. 
64.Lee, J.H.; Talcott, S.T. Fruit maturity and juice extraction influences ellagic acid derivatives and other antioxidant polyphenolics in muscadine grapes. J. Agric. Food Chem., 2004, 52, 361-366.

65.Narayanan, B.A.; Geoffroy, O.; Willingham, M.C.; Re, G.G.; Nixon, D. p53/p21(WAF1/CIP1) expression and its possible role in G1 arrest and apoptosis in ellagic acid treated cancer cells. Cancer Lett, 1999, 136, 215-221.

66.Han, D.H.; Lee, M.J.; Kim, J.H. Antioxidant and apoptosis-inducing activities of ellagic acid. Anticancer Research, 2006, 26, 3601-3606.

67. Festa, F.; Aglitti, T.; Duranti, G. et al. Strong antioxidant activity of ellagic acid in mammalian cells in vitro revealed by the comet assay. Anticancer Res 2001, 21:3903-3908.

68. Corbett, S.; Daniel, J.; Drayton, R.; Field, M.; Steinhardt, R.; Garrett, N. Evaluation of the anti-inflammatory effects of ellagic acid. J. PeriAnesthesia Nursing, 2010, 25, 4, 214 220 .

69. Lamer-Zarawska, E.; Oszmiański, J. Rola niektórych substancji roślinnych w profilaktyce przeciwnowotworowej. Wiad Ziel 1998, 5, 1-4.

70. Kwiatkowska, E. Kwas elagowy - zawartość w żywności i rola prozdrowotna. Post. Fitoter. 2010, 4, 211-214.

71.Sepúlveda, L.; Ascacio, A.; Rodríguez-Herrera, R.; Aguilera-Carbó, A.; Aguilar, C.N. Ellagic acid: Biological properties and biotechnological development for production processes. Afr. J. Biotechnol. 2011, 10, 22, 4518-4523.

72.Lutomski, J.; Alkiewicz, J. Leki roślinne w profilaktyce i terapii. PZWL: Warszawa, 1993.

73.Kohlmunzer, S. Farmakognozja. PZWL, Warszawa, 1993.

74. Schmid, B.; Kötter, I.; Heide, L. Pharmacokinetics of Salicin after Oral Administration of a Standardised Willow Bark Extract. Eur. J. Clin. Pharmacol. 2001 57, 387-391.

75. Schmid, B.; Lüdtke, R.; Selbmann, H.; K., Kötter, I.; Tschirdewahn, B.; Schaffner, W.; Heide, L. Efficacy and Tolerability of a Standardized Willow Bark Extract in Patients with Osteoarthritis: Randomized Placebo-controlled Double Blind Clinical Trial. Phytother. Res. 2001, 15, 344-50.

76.Międzybrodzki, R. Kierunki poszukiwań i zastosowanie niesteroidowych leków przeciwzapalnych. Postępy Higieny i Medycyny Doświadczalnej, 2004, 58, 438-448.

77.Zejc, A.; Gorczyca, M. (red.) Chemia leków. PZWL: Warszawa, 2004.

78.Vlot, A.C.; Dempsey, D.A.; Klessig, D.F. Salicylic acid, a multifaceted hormone to combat disease. Annu Rev Phytopathol, 2009;47,177-206.

79.Ożarowski, A.; Jaroniewski, W. Rośliny lecznicze i ich praktyczne zastosowanie IWZW 26 
Warszawa, 1987.

80. Flos Pini masculinum - kwiat męski sosny w fitoterapii, http://rozanski.li/1750/flos-pinimasculinum-kwiat-meski-sosny-w-fitoterapii/ (13.06.2019).

81. Świerk picea w fitoterapii, http://rozanski.li/1288/swierk-picea-w-fitoterapii/ (13.06.2019).

82. Fitoterapia, http://www.rozanski.ch/fitoterapia1.htm, (13.06.2019).

83. Fernández de Simón, A.; Cadahía, B.; Conde E.; García-Vallejo E.; M.C. Low molecular weight phenolic compounds in spanish oak woods. J. Agric. Food Chem. 1996, 44, $1507-1511$.

84. Del Alamo Sanza, M.; Nevares Domınguez, I.; Cárcel Cárcel, L.M.; Navas Gracia, L. Analysis for low molecular weight phenolic compounds in a red wine aged in oak chips. Anal. Chim. Acta 2004, 513, 229-237.

85. Regalado, E.L.; Tolle, S.; Pino, J.A.; Winterhalter, P.; Menendez, R.; Morales, A.R.; Rodríguez, J.L. Isolation and identification of phenolic compounds from rum aged in oak barrels by high-speed countercurrent chromatography/high-performance liquid chromatography-diode array detection-electrospray ionization mass spectrometry and screening for antioxidant activity. J. Chromatogr. A 2011, 1218, 7358-7364.

86. Pobłocka-Olech, L. Zastosowanie metod chromatograficznych w badaniach składu chemicznego kory niektórych gatunków i klonów wierzby, PhD dissertation, Medicial Academy, Farmecautical Department, Gdańsk 2006

87. Bisset, N.; Wichtl M. Herbal drugs and phytopharmaceuticals. CRC, London 2001.

88. Duke, J.A.: Handbook of phytochemical constituents of GRAS herbs and other economic plants. CRC, London 1992.

89. Sharma, V.; Voil, N. Age-related changes in indolic and phenolic compounds in leaves from enforced Salix shoot. Indian J. Plant Physiol. 1997, 42, 207.

90. Keapigu, M.C.; Wang, M. Chemical studies on antituberculosis compounds from Salix capitata. Zhongguo Daxue Xuebao, 1996, 27, 271

91. Najda, A.; Bekier, J.; Guleac, E.; Filiks, A. Profil kwasów fenolowych liści brzozy brodawkowatej (Betula pendula roth) [Phenolic acid profile of silver birch (Betula pendula roth) leaves] episteme 25/2014 pp. 77-85 ISSN 1895-4421

92.Fong, H.H.S.; Bauman, J.L, Hawthorn. J. Cardiovasc Nurs 2002; 16:1-8

93.Olszewska, M.; Prester, A.; Michel, P. et al. Profiling of phenolic compounds and antioxidant activity of dry extracts from the selected Sorbus species. Molec 2012; 17,3, 3093-3113. 
94. Dimkić, I.; Ristivojević, P.; Janakiev, T.; Berić, T.; Trifković, J.; Milojković-Opsenica, D.; Stanković, S. Phenolic profiles and antimicrobial activity of various plant resins as potential botanical sources of Serbian propolis. Ind Crop Prod 2016, 94,856-871

95. Slavin, J.; Marquart, L.; Jakobs, D. Jr.: Consumption of whole-grain food and decreased risk of cancer: proposed mechanisms. Cereal Foods World, 2000, 45, 2, 54-58.

96.Geissmann, T.A. The chemistry of flavonoid compounds. Pergamon Press, Oxford 1962

97.Bravo L.: Polyphenols: Chemistry, dietary, sources, metabolism, and nutritional significance. Nutr. Rev. 1998, 56, 11, 317-333.

98.Colette N., et al.: Antioxidant properties of hydroxyflavones. Free Radic. Biol. Med. 1996, 20.

99.Ligor, M. Polifenole. [In:] Badanie substancji biologicznie aktywnych w surowcach roślinnych i produktach naturalnych $\mathrm{z}$ zastosowaniem łączonych technik chromatograficznych. Ligor M (red). UMK, Toruń 2013, 55-63.

100. Lamer-Zarawska, E. Flawonoidy, fitoterapia i leki roślinne. PZWL, Warszawa, Poland, 2007, pp. 64-67.

101. Benhamou, N.; Nicole, M. Cell biology of plant immunization against microbial infection: the potential of induced resistance in controlling plant diseases. Plant Physiol Bioch., 1999, 37, 703-719.

102. Skipp, RA.; Bailey, JA. The fungitoxicity of isoflavonoid phytoalexins measured using different types of bioassay. Physiol Mol Plant P., 1977, 11, 101-112.

103. Phillips, DA.; Kapulnik, Y. Plant isoflavonoids, pathogens and symbionts. Trends Microbiol., 1995, 3, 58-64.

104. Dakora, FD.; Phillips, DA. Diverse functions of isoflavonoids in legumes transcend antimicrobial definitions of phytoalexins. Physiol Mol Plant P., 1996, 49, 1-20.

105. Middleton, E.; Kandaswami, C.; Theoharides, TC. The effects of plant flavonoids on mammalian cells: implications for inflammation, heart disease, and cancer. Pharmacological Reviews, 2000, 52, 4, 673-751.

106. Cushman, M.; Nagarthan, D. Cytotoxicities of some flavonoid analogues. J Nat Prod., 1991, 54, 1656-1660.

107. Miranda, CL.; Stevens, JF.; Helmrich, A.; Henderson, MC.; Rodriguez, RJ.; Yang, YH.; Deinzer, ML.; Barnes, DW.; Buhler, DR. Antiproliferative and cytotoxic effects of phenylated flavonoids from human cancer cell lines. Food Chem Toxicol., 1999, 37, 271-274.

108. Caltagirone, S.; Rossi, C.; Poggi, A.; Ranelletti, FO.; Natali, PG.; Brunetti, M.; Aiello, 28 
FB.; Piantelli, M. Flavonoids apigenin and quercetin inhibit melanoma growth and metastatic potential. Int J Cancer., 2000, 15, 587-595.

109. Galanty, A.; Janeczko, Z. Badanie wpływu Citroseptu na przeżywalnosć komórek nowotworowych in vitro Post Fitoter., 2003, 1, 16-18.

110. Laracine-Pittet, C.; Lebreton, P. Flavonoid variability within Pinus sylvestris, Phytochem., 1988, 27, 8, 2663-2666.

111. Oleszek, W.; Stochmal, A.; Karolewski P.; Simonet AM.;. Macias, FA.; Tava, A. Flavonoids from Pinus sylvestris needles and their variation in trees of different origin grown for nearly a century at the same area. Biochem Syst Ecol., 2002, 30, 1011-1022.

112. Viriot, C.; Scalbert, A.; Lapierre, C.; Moutounet, M. Ellagitannins and lignins in aging of spirits in oak barrels. J. Agric. Food Chem. 1993, 41, 1872-1879.

113. Vovk, I.; Simonovska, B.; Andrenšek, S.; Vuorela, H. Rotation planar extraction and rotation planar of oak Quercus robus L bark. J Chromatogr A., 2003, 991, 267-274.

114. Broda, B.; Mowszowicz, J. Przewodnik do oznaczania roślin leczniczych, trujących i użytkowych. [Guide for the determination of medicinal, poisonous and usable plants]. PZWL, Warszawa, Poland, 2000.

115. Sulima, P.; Krauze-Baranowska, M.; Przyborowski, JA. Variations in the chemical composition and content of salicylic glucosides in the bark of Salix purpurea from natural locations and their significance for breeding. Fitoterapia, 2017, 118, 118-125.

116. Salix in practical phytotherapy, http://rozanski.li/438/wierzba-salix-w-praktycznejfitoterapii/ (13.06.2019)

117. Harborne, JB.; Baxter, H. The handbook of natural flavonoids. Willey, Chichester, 1999.

118. Dimkić, I.; Ristivojević, P.; Janakiev, T.; Berić, T.; Trifković, J.; Milojković-Opsenica, D.; Stanković, S. Phenolic profiles and antimicrobial activity of various plant resins as potential botanical sources of Serbian propolis. Ind Crop Prod., 2016, 94, 856-871.

119. Thapliyal, R.P.; Bahugana, R.P. Fatty acids and flavonoids of Salix Lindlevana. Int J Pharmacog., 1993, 31, 165- 166.

120. Gorobets, AB.; Bandyukova. VA.; Shapirom, DK. Flavonoid composition of pollen of Salix caprea and S. alba. Khim Prir Soedin., 1982, 6, 781-782.

121. Fong, H.H.S.; Bauman, J.L. Hawthorn. J. Cardiovasc Nurs., 2002, 16, 1-8.

122. Dawidowicz, AL.; Wianowska, D.; Baraniak, B. The antioxidant properties of alcoholic extracts from Sambucus nigra L.(antioxidant properties of extracts). LWT Food Sci Technol., 2006, 39, 3, 308-315.

123. Christensen, LP.; Kaack, K.; Fretté, XC. Selection of elderberry (Sambucus nigra L.) 29 
genotypes best suited for the preparation of elderflower extracts rich in flavonoids and phenolic acids. Eur Food Res Technol., 2008, 227, 1, 293-305.

124. Dallenbach-Toelke, K.; Nyiredy, S.; Gross, G.A.; Sticher, O. Flavonoid Glycosides from Betula pubescens and Betula pendula. J. Nat. Prod., 1986, 496, 1155-1156.

125. Olszewska, M.; Prester, A.; Michel, P. Profiling of phenolic compounds and antioxidant activity of dry extracts from the selected Sorbus species. Molec., 2012, 17, 3, 30933113.

126. Krauze-Baranowska, M. Flavonoids from the genus Taxus. Z Naturforsch C., 2004, 59, 43-47.

127. Sergent, T.; Kohnen, S.; Jourez, B.; Beauve, C.; Schneider, Y.J.; Vincke, C. Characterization of black locust (Robinia pseudoacacia L.) heartwood extractives: identification of resveratrol and piceatannol. Wood Sci Technol., 2014, 48, 1005-1017.

128. Piątkowska, E.; Kopeć, A.; Leszczyńska, T. Antocyjany - charakterystyka, występowanie i oddziaływanie na organizm człowieka. Żywność. Nauka. Technologia. Jakość, 2011, 4, 77, 24-35.

129. Wilska-Jeszka. Polifenole, glukozynolany i inne związki prozdrowotne i antyżywieniowe. Chemia żywności. T. I. Składniki żywności. Red. Sikorski, ZE., WNT, Warszawa, Poland, 2007, pp. 206 - 226.

130. Lila, MA. Anthocyanins and human health: an in vitro investigative approach. J Biomed Biotech., 2004, $306-313$.

131. Zhang, Z.; Chang, Q, Zhu M. Characterization of antioxidants present in hawthorn fruits. J Nutr Biochem., 2001, 12, 3, 144-152.

132. Fong, HHS.; Bauman, JL. Hawthorn. J. Cardiovasc Nurs., 2002, 16, 1-8.

133. Grimm, T.; Schäfer, A.; Högger, P. Antioxidant activity and inhibition of matrix metalloproteinases by metabolites of maritime pine bark extract (pycnogenol). Free Radic Biol Med., 2004, 36, 6, 811-822.

134. Uhlenhut, K.; Högger, P. Facilitated cellular uptake and suppression of inducible nitric oxide synthase by a metabolite of maritime pine bark extract (Pycnogenol). Free Radic Biol Med., 2012, 53, 2, 305-313.

135. Lila, MA. Anthocyanins and human health: an in vitro investigative approach. J Biomed Biotech., 2004, 5, 306-313.

136. Kobylińska, A.; Janas, M.K. Prozdrowotna rola kwercetyny obecnej w diecie człowieka Health. [Promoting effect of quercetin in human diet] Postepy Hig Med Dosw (online), 2015, 69, 51-62 
Olejnik, A.; Tomczyk, J.; Kowalska, K.; Grajek, W. Antocyjany w chemoprewencji nowotworu jelita grubego. Postępy Fitoterapii, 2009, 3, 180-188.

138. Nielsen, IL.; Rasmussen, SE.; Mortensen, A.; Ravn-Haren, G.; Ma, HP.; Knuthsen, P.; Hansen, BF.; McPhail, D.; Freese, R.; Breinholt, V.; Frandsen, H.; Dragsted, Lo. Anthocyanins increase low-density lipoprotein and plasma cholesterol and do not reduce atherosclerosis in Watanabe heritable hyperlipidemic rabbits. Molec.r Nutr. Food Res., 2005, 49, 301-308.

139. Muszyński, S.; Guzewski, W. Antocyjany roślin wyższych. PTB Kraków, 1976, 20, 4.

140. Gupta, RK.; Hasla, E. Plant proanthocyanidins. Part 7. Prodelphinidins from Pinus sylvestris. Chem. Soc., Perkin Trans. 1981, pp. 1148-1150.

141. Karapandzova, M.; Stefkov, G.; Cvetkovikj, I.; Stanoeva, JP.; Stefova, M.; Kulevanova, S. Flavonoids and other phenolic compounds in needles of pinus peuce and other pine species from the macedonian flora. Nat Prod Commun., 2015, 10, 6, 987-990.

142. Nam-Young, K.; Min-Kyung, J.; Dong-Geun, L.; Ki Hwan,Y.; Hye Ji J.;Mihyang K.; Sung Gu K.;Byung, Hong Y.; Sang-Hyeon L. Comparison of methods for proanthocyanidin extraction from pine (Pinus densiflora) needles and biological activities of the extracts. Nutr. Res.Pract. 2010, 4, 16-22.

143. Chang, Sub K.; Sung, Phil M.; Jeong Phil J. Effects of Water Extraction Temperatures on the Yield, Molecular Weight, and Antioxidant Activity of Proanthocyanidins Extracted from Pinus radiata Bark. Forest Prod J., 2011, 61, 4, 321-325.

144. Vivas, N.; Nonier, M.; Pianet, I.; Vivasdegaulejac, N.; Fouquet, E. Proanthocyanidins from Quercus petraea and Q. robur heartwood: quantification and structures. C R Chim., 2006, 9,120-126.

145. Pallenbach, E.; Scholz E.; König, M.; Rimpler H. Proanthocyanidins from Quercus petraea Bark. Plant Med., 1993, 59, 3, 264-268.

146. Oak in phytotherapy, http://rozanski.li/1193/quercus-dab-w-fitoterapii/ (13.06.2019)

147. Yang, B.; Liu, P. Composition and health effects of phenolic compounds in hawthorn (Crataegus spp.) of different origins. J Sci Food Agric., 2012, 92, 8, 1578-1590.

148. Kumar, D.; Arya, V.; Bhat, ZA.; Khan, NA.; Prasad, DN. The genus Crataegus: chemical and pharmacological perspectives. Revista Brasileira de Farmacognosia, 2012, 22, 5, 1187-1200.

149. Kucharska, AZ.; Oszmański, J. Anthocyanins in fruits of Prunus padus (bird cherry). J. Sci. Food Agr., 2002, 82, 13, 1483-1486.

150. Bridle, P.; Stott, KG.; Timberlake, CF. Anthocyanins in Salix species: a new anthocyanin 31 
in Salix purpurea bark. Phytochemistry, 1973, 12, 1103-1106.

151. Morales, M.; Ros Barcelo, A.; Pedreno, MA. Plant stilbenes: recent advances in their chemistry and biology. Advances in Plant Physiology, 2000, 3, 39-70.

152. Bavaresco, L.; Fregoni, C.; Cantu, E; Trevisan, M. Stilbene compounds: from the grapevine to wine. Drugs Exp Clin Res., 1999, 25, 57-63.

153. Roupe, KA.; Remsberg, CM.; Yanez, JA.; Davies, NM. Pharmacometrics of stilbenes: seguing towards the clinic. Curr Clin Pharmacol., 2006, 1, 81-101.

154. Gu, X.; Chu, Q.; O’Dwyer, M.; Zeece, M. Analysis of resveratrol in wine by capillary electrophoresis. J Chromatogr A., 2000, 881, 471-481.

155. Shakibaei, M.; Harikumar, KB.; Aggarwal, BB. Resveratrol addiction: to die or not to die. Mol Nutr Food Res., 2009, 53, 115-112.

156. Arichi, H.; Kimura, Y.; Okuda, H.; Baba, K.; Kozawa, M.; Arichi, S. Effects of stilbene components of the roots of Polygonum cuspidatum Sieb. et Zucc. on lipid metabolism. Chem Pharm Bull (Tokyo), 1982, 30, 1766-1770.

157. Jang, M.; Cai, L.; Udeani, GO.; Slowing, KV.; Thomas, CF.; Beecher, CW.; Fong, HH,; Farnsworth, NR.; Kinghorn, AD.; Mehta, RG.; Moon, RC.; Pezzuto, JM. Cancer chemopreventive activity of resveratrol, a natural product derived from grapes. Science, 1997, 275, 218-220.

158. Lange, BM.; Trost, M.; Heller, W.; Langebartels, C.; Sandermann, H. Elicitor-induced formation of free and cell-wall-bound stilbenes in cell-suspension cultures of Scots pine (Pinus sylvestris L.) Planta, 1994, 194: 143 - 148.

159. Riviere, C.; Pawlus, AD.; Merillon, JM. Natural stilbenoids: distribution in the plant kingdom and chemotaxonomic interest in Vitaceae. Nat Prod Rep., 2012, 29, 13171333.

160. Fliegmann, J.; Schröder, G.; Schanz, S; et al. Molecular analysis of chalcone and dihydropinosylvin synthase from Scots pine (Pinus sylvestris), and differential regulation of these and related enzyme activities in stressed plants. Plant Mol Biol, 1992, 18, 489-503 https://doi.org/10.1007/BF00040665

161. Erdtman, H.; Misiorny, A. Constituents of pine heartwood. XXXI. The content of pinosylvin phenols in Swedish pines. Svensk Papper. 1952, 55, 605-8.

162. .Kiselev, K.V.; Grigorchuk, V.P.; Ogneva Z.V.; Suprun A.R,; Dubrovina, A.S. Stilbene biosynthesis in the needles of spruce Picea jezoensis Phytochemistry 2016, 131, 57-67

163. Sheng-Hong, Li.; Xue-Mei, N.; Zahn, S.; Gershenzon, J.; Weston, J.; Schneider, B. Diastereomeric stilbene glucoside dimers from the bark of Norway spruce (Picea abies 


\section{L.), Phytochem.,2008, 69, 772-782.}

164. Ganthaler, A.; Stöggl, W.; Mayr, S.; Kranner, I.; Schüler, S.; Wischnitzki, E.; Fluch, E.V.; Trujillo-Moya S.C. Association genetics of phenolic needle compounds in Norway spruce with variable susceptibility to needle bladder rust. Plant Mol Biol, 2017, 94, 229. https://doi.org/10.1007/s11103-017-0589-5

165. Sergent, T.; Kohnen, S.; Jourez, B.; Beauve, C.; Schneider, Y.J.; Vincke, C. () Characterization of black locust (Robinia pseudoacacia L.) heartwood extractives: identification of resveratrol and piceatannol. Wood Sci Technol, 2014, 48,1005-1017

166. Song, W.; Wang, H.J.; Zhang, P.F.; Wei, D.Z.; Lu, Y. Phytochemical Profiles of Different Mulberry (Morus sp.) Species from China. J Agric Food Chem. 2009, 57 (19), 91339140. 10.1021/jf9022228.

167. Schultz, T.P.; Hubbard, T.F.; Jin, L.; Fisher, T.H.; Nicholaus, D.D.. Role of stilbenes in the natural durability of wood: fungicidal structure activity relationships. Phytochemistry, 1990, 29 (5), 1501-1507.

168. Chong, J.; Poutaraud, A.; Hugueney, P.. Metabolism and roles of stilbenes in plants. Plant Science, 2009, 177 (3), 143-155.

169. Suga, T.; Ohta, S.; Munesada, K.; Ide, N.; Kurokawa, M.; Shimizu, M.; Ohta, E. Endogenous pine wood nematicidal substances in pines, Pinus massoniana, P. strobus and P. palustris. Phytochemistry 1993, 33, 1395-1401.

170. Cooper, R.A.; Strauss, J.F. III (1984) Regulation of cell membrane cholesterol. In: Shinitzky M (ed) Physiology of membrane fluidity, vol 1. CRC Press, Boca Raton, pp 73-97

171. Batta, A.K.; Xu, G.; Honda, A.; Miyazaki, T.; Salen, G: Stigmasterol reduces plasma cholesterol level and inhibits hepatic synthesis and intestinal absorption in the rat. Metab. Clin. Exp., 2006, 55, 292-299.

172. Moghadasian M.H., Frohlich J.J.: Effect of dietary phytosterols on cholesterol metabolism and atherosclerosis: clinical and experimental evidence. Am. J. Med., 1999, 107, 588-594.

173. Patel, M.D.; Thompson, P.D. Phytosterols and vascular disease. Atherosclerosis, 2006, $186,12-19$

174. Saranpää, P. and H. Nyberg.. Seasonal variation of neutral lipids in Pinus sylvestris L. sapwood and heartwood. Trees, 1987, 1, 139-144

175. Piispanen, R.; Saranpää, P. Seasonal and within-stem variations of neutral lipids in silver birch (Betula pendula) wood. Tree Physiol., 2004,24(9), 991-9. 
176. Saranpää, P.; Nyberg, H. Lipids and sterols of Pinus sylvestris L. sapwood and heartwood. Trees, 1987, 1,82-87

177. Hillinger, C.; Höll, W.; Ziegler, H. Lipids and lipolytic enzymes in the trunkwood of Robinia pseudoacacia L. during heartwood formation. I. Radial distribution of lipid classes. Trees, 1996, 10, 366-375.

178. Stuper-Szablewska, K.; Rogoziński, T.; Perkowski, J. Contamination of pine and birch wood dust with microscopic fungi and determination of its sterol contents. Arh Hig Rada Toksikol 2017, 68,127-134

179. Rowe J.W. The sterols of pine bark. Phytochemistry 1965,4, 1-10

180. Mészáros E, Jakab E.; Várhegyi, G. TG/MS, Py-GC/MS and THM-GC/MS study of the composition and thermal behavior of extractive components of Robinia pseudoacacia. $J$ Anal Appl Pyrolysis, 2007, 79,61-70

181. Dong, H.; Zhang TP, Peng SM, et al. Extraction of sitosterol from hawthorn fruits and effect of sitosterol on immunological function and serum lipid. Nat Prod Res Dev, 2009, 21, 60-63.

182. Bakkali, F.; Averbeck, S.; Averbeck, D.; Idaomar, M: Biological effect of essentials oils a review. Food Chem. Toxicol., 2008, 46, 446-475

183.Trytek, M.; Paduch, R.; Fiedurek, J.; Kandefer-Szerszeń, M. Monoterpeny - stare związki, nowe zastosowania i biotechnologiczne metody ich otrzymywania. Biotechnologia, 2007, 1,135-155

184. Głowacki, S. Zawartość olejków eterycznych w igliwiu drzew leśnych. Sylwan. 1994, 1, $27-42$.

185. Radulescu, V.; Saviuc, C.;Chifiriuc C, Oprea E.;Visan D.C.; Marutescu L.; Lazar V., Chemical composition and antimicrobial activity of essential oil from shoots Spruce (Picea abies L). Rev Chim, 2011, 62, 69-74

186. Nowak, G.; Nawrot, J. Surowce roślinne i związki naturalne stosowane w chorobach układu oddechowego. Herba Polonica, 2009, 55, 178-213

187. Judžentienè, A.; Šližytė, J.; Stiklienè, A;. Kupčinskienė, E. Characteristics of essential oil composition in the needles of young stand of Scots pine (Pinus sylvestris L.) growing along aerial ammonia gradient Chemija, 2006, 17,67-73

188. Kicel, A.; Olszewska, M.A.; Owczarek, A.; Wolbiś, M. () Preliminary study on the composition of volatile fraction of fresh flowers and leaves of Robinia pseudoacacia L., growing in Poland. Acta Pol Pharm, 2015, 72, 1217-1222

189. Krasutsky, P.A. Birch bark research and development. Nat Prod Rep, 2006; 23, 919-942. 
190.Kuźma, P.; Balcer, A.; Staniszewski, P.; Obiedziński, M.W. Porównanie składu olejek eterycznych igliwia jodły( Abies alba Mill.) pochodzącej ze stanowisk zróżnicowanych pod względem wysokości nad poziomem morza. ABID, 2014, 19, 47-51

191. Wajs, A.; Urbańska, J.; Zaleśkiewicz, E.; Bonikowski, R. Composition of essential oil from seeds and cones of Abies alba, Nat. Prod. Commun., 2010, 5, 1-4.

192. Majewska, E.; Kozłowska, M.; Kowalska, D .; et al. Characterization of the essential oil from cone-berries of Juniperus communis L. (Cupressaceae). Herba Pol, 2017; 63(3),48-55.

193. Damjanović, B.; Skala, D.; Baras, J.; Petrović Djakov, D. Isolation of essential oil and supercritical carbon dioxide extract of Juniperus communis L. fruits from Montenegro. Flavour and Fragrance Journal, 21, 2006,875-880.

194. Hajdari, A.; Mustafa, B.; Gashi, V.; Nebija, D.; Ibraliu, A.; Novak, J. Chemical composition of the essential oils of ripe berries of Juniperus oxycedrus L., growing wild in Kosovo. Biochemical Systematics and Ecology, 2014, 57, 90-94.

195. Gonny, M.; Cavaleiro, C.; Salgueiro, L.; Casanova, J. Analysis of Juniperus communis subsp. alpina needle, berry, wood and root oils by combination of GC, GC/MS and 13CNMR. Flavour and Fragrance Journal, 2006, 21, 99-106. https://doi.org/10.1002/ffj.1527. 